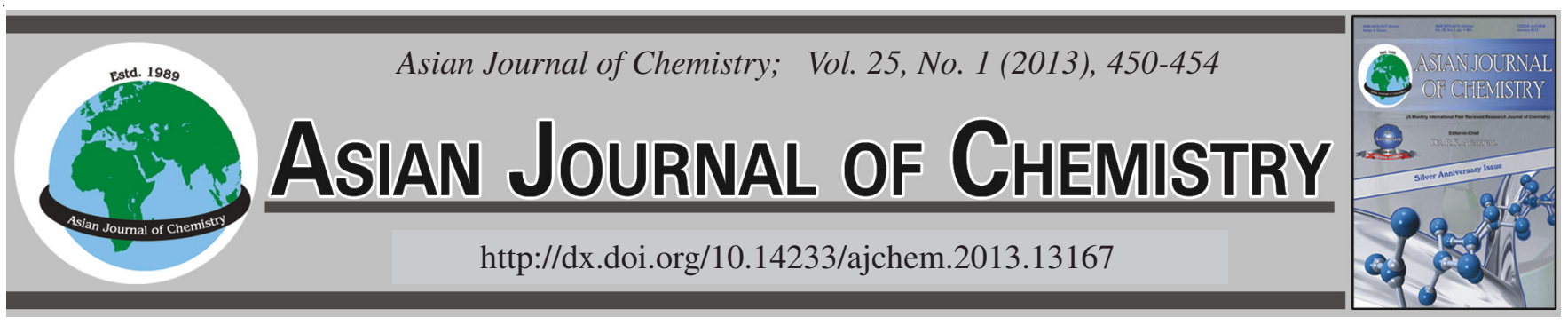

\title{
Pollution Monitoring Using Mytilus galloprovincialis and \\ Fishes: A Case Study on the Southern Black Sea Shelf
}

\author{
N. BALKIS ${ }^{1, *}$, A. AKSU ${ }^{1}$ and H. HiçSÖNMEZ ${ }^{2}$
}

\begin{abstract}
${ }^{1}$ Department of Chemical Oceanography, Istanbul University, Institute of Marine Science and Management, Vefa 34134-00, Istanbul, Turkey
\end{abstract} ${ }^{2}$ Istanbul Province National Education Directorate, Turkey

*Corresponding author: Fax: +90 212 5268433; Tel: +90 212 4400000/26053; E-mail: nbal@ istanbul.edu.tr

(Received: 3 December 2011;

Accepted: 30 July 2012)

AJC-11898

\begin{abstract}
In this study, the heavy metal bioaccumulations in mussels (Mytilus galloprovincialis) and fishes (Merlangius merlangus euxinus) have been studied along the Southern Black Sea Shelf. Generally, $\mathrm{Pb}$ and $\mathrm{Cd}$ contents were higher than the critical limits set by the Turkish Ministry of Environment for Aquatic Products $\left(1 \mu \mathrm{g} \mathrm{g}{ }^{-1}\right.$ wet wt. and $0.1 \mu \mathrm{g} \mathrm{g}^{-1}$ wet wt., respectively) and European countries $\left(2.0 \mu \mathrm{g} \mathrm{g}{ }^{-1}\right.$, UNEP, 1985). They showed increases towards the eastern end of the shelf. As contents were observed higher than the critical limits set by the Turkish Ministry of Environment for Aquatic Products (1.0 $\mu \mathrm{g} \mathrm{g}^{-1}$ wet wt.) at stations Terkos, Samsun and Ordu in 2009. In contrast, $\mathrm{Hg}$ levels were also higher than the critical limits set by the Turkish Ministry of Environment for Aquatic Products $\left(0.5 \mu \mathrm{g} \mathrm{g} \mathrm{g}^{-1}\right.$ wet wt.) in 2005 and the highest $\mathrm{Hg}$ concentrations were found in the west and middle of the shelf.
\end{abstract}

Key Words: Black sea, Metal, Pollution, Mytilus galloprovincialis, Fish.

\section{INTRODUCTION}

The Black Sea is an inland marine basin located north of Turkey. Of all the inland seas, such as the Baltic sea or the Mediterranean, it is the most isolated from the oceans. It is connected to the Mediterrenean via the Bosphorus, the Marmara sea and the Dardanelles. The Black Sea, with a surface area of $423,000 \mathrm{~km}^{2}$, is approximately one-fifth of the surface area of the Mediterranean. It has a total volume of $547,000 \mathrm{~km}^{3}$ and a maximum depth of around $2200 \mathrm{~m}$.

The northwestern shelf, occupying $c a .20 \%$ of the total area, is the only major shelf region with discharges from three of Europe's largest rivers i.e., Danube, Dnieper and Dniester ${ }^{1}$. Black Sea has always been a basin with a positive water balance. According to the data presented by Unluata ${ }^{2}$ as well as by Ozsoy and Unluata ${ }^{3}$, the sum of fluxes due to precipitation (ca. $300 \mathrm{~km}^{3}$ peryear) and runoff ( $c a .350 \mathrm{~km}^{3}$ peryear) exceeds that of evapouration ( $c a .350 \mathrm{~km}^{3}$ per year). The freshwater excess of $300 \mathrm{~km}^{3}$ per year is balanced by the net outflow through the bosphorus, defined as the difference between the transports of its two layers. Danube river alone brings about $200 \mathrm{~km}^{3} /$ year water discharge, which corresponds to $3 / 4$ of the north-western river runoff and $2 / 3$ of the total riverine input $\left(370 \mathrm{~km}^{3} /\right.$ year $)$ into the basin. Turkish rivers $\left(0.275 \times 10^{3}\right.$ tons/ year) account for $1 / 3$ of the Danube $\left(0.913 \times 10^{3}\right.$ tons/year $)$ and all other rivers on the northern part of the Black Sea $(0.977$ $\times 10^{3}$ tons/year) ${ }^{4}$. Approximately 19 million people live in the coastal zone of the Black Sea. The population is the densest on the Turkish and Ukrainian coasts.

In recent years, aquatic ecosystems have been contaminated by heavy metals; which are of agricultural, industrial, domestic, mining and also natural origins ${ }^{5,6}$. They are potentially toxic to the aquatic environment. If they exceed natural limits, they will be harmful to the aquatic organisms' environments and human health ${ }^{7}$. Organisms need some metals such as $\mathrm{Fe}, \mathrm{Cu}, \mathrm{Zn}, \mathrm{Co}, \mathrm{Se}, \mathrm{Ni}$ and $\mathrm{Mn}$ in certain amounts. However, exceeding these amounts may cause toxic effects for these organisms. Some metals such as $\mathrm{Hg}, \mathrm{Cr}, \mathrm{Pb}$ and $\mathrm{Cd}$ are toxic to organisms and marine habitat. These metals are dissolved in sea water or suspended in solid materials and absorbed through the gills or skin of marine organisms. They also accumulate in the bodies of organisms through the food chain ${ }^{7}$. Mussels, in particular, have been used as biological indicator organisms to monitor marine pollution by toxic heavy metals and potentially toxic chemicals due to their properties of inhabitation $^{8,9}$.

In this study, the metal bioaccumulations in mussels (Mytilus galloprovincialis) and fishes (Merlangius merlangus euxinus) have been investigated via a four-year monitoring program (2005-2009) from Igneada to Hopa. Furthermore, this paper presents the first results of arsenic content in all biaota samples along the Southern Black Sea shelf. Turkey is 


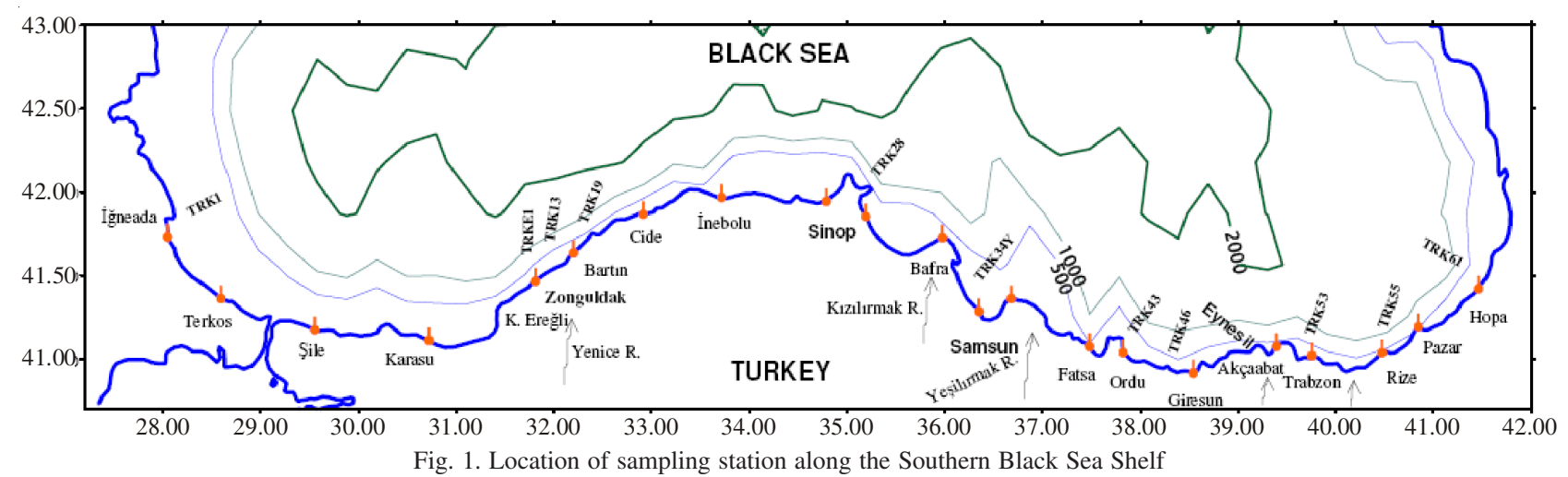

a member of the commission on the protection of the Black Sea against pollution. Thus, these results form a base for future studies.

\section{EXPERIMENTAL}

The samples of mussels (Mytilus galloprovincialis) and fishes (Merlangius merlangus euxinus) were collected from hot points (harbours and river mouths) from 2005 to 2009 (Fig. 1, Table-1). After collection, the samples were placed in polyethylene bags and stored below $-20^{\circ} \mathrm{C}$ pending analysis ${ }^{10}$. For total metal analysis, approximately 10-12 the ripe mussels (Mytilus galloprovincialis) (the length vary between 10 and 15 $\mathrm{cm}$ ) and fishes (Merlangius merlangus euxinus) taken from each station were dissected according to UNEP ${ }^{11}$. The fillets were homogenized in a blender and approximately 5-7 g of homogenate (fish) was digested with 5:3 $\mathrm{HNO}_{3}: \mathrm{H}_{2} \mathrm{SO}_{4}$ in microwave digestion system and then diluted to the desired volume with $1 \mathrm{~N} \mathrm{HNO}_{3}{ }^{11-13}$. All the analyses were performed using an atomic absorption spectrophotometer (Shimadzu 6701). The total mercury concentration was measured using a cold vapour technique and hydride generator unit (HVG-1 hydride vapour generator). $\mathrm{Cd}$ and $\mathrm{Pb}$ levels were also determined with a flame furnace; background corrections were used as required. The detection limits for trace metals were $\mathrm{Hg}$ : 0.05, Cd:0.10 and $\mathrm{Pb}: 0.10 \mathrm{mg} \mathrm{L}^{-1}$. The accuracy and precision of the analyses was checked by analyzing BCR reference material CRM142 and IAEA-MEL reference material IAEA436 and IAEA433 (Table-2). The analytical precision of the analysis was better than $10 \%$ at $95 \%$ significance level from five replicates.

\section{TABLE-1}

\section{GPS DATA OF SAMPLING LOCATIONS IN THIS STUDY}

\begin{tabular}{lcc}
\hline Station & Longitude & Latutide \\
\hline Igneada & 417.670 .825 .834 & 28.104 .292 .295 \\
Terkos & 419.697 .679 .352 & 284.268 .425 .765 \\
Sakarya & 412.143 .048 .056 & 307.215 .560 .785 \\
Zonguldak & 415.183 .334 .583 & 317.997 .952 .693 \\
13A & 418.039 .343 .519 & 317.813 .632 .531 \\
19A & 419.421 .294 .213 & 329.056 .812 .341 \\
Sinop & 418.960 .643 .982 & 352.464 .722 .761 \\
Bafra & 424.764 .806 .899 & 353.201 .978 .403 \\
Samsun & 413.248 .601 .112 & 364.076 .530 .392 \\
Ordu & 410.668 .977 .315 & 379.005 .988 .417 \\
Giresun & 409.228 .333 .333 & 384.018 .333 .333 \\
Trabzon & 411.129 .627 .546 & 393.935 .446 .441 \\
Rize & 410.761 .109 .861 & 404.349 .210 .528 \\
Hopa & 41.453 .841 .926 & 414.117 .866 .549 \\
\hline
\end{tabular}

TABLE-2

PRECISION OF THE ANALYSIS FROM FIVE REPLICATE SAMPLES AND CERTIFIED AND MEASURED CONTENTS OF REFERENCE MATERIALS IN THIS STUDY

\begin{tabular}{ccccc}
$\begin{array}{c}\text { Reference } \\
\text { material }\end{array}$ & Element & $\begin{array}{c}\text { Precision } \\
(\%)\end{array}$ & $\begin{array}{c}\text { Measured value } \\
\left(\text { this study) }\left(\mu \mathrm{g} \mathrm{g}^{-1}\right)\right.\end{array}$ & $\begin{array}{c}\text { Certified value } \\
\left(\mu \mathrm{g} \mathrm{g}^{-1}\right)\end{array}$ \\
\hline CRM142 & $\mathrm{Fe}$ & 8 & $46000 \pm 200$ & $40300-41300$ \\
CRM142 & $\mathrm{Cu}$ & 8 & $25 \pm 0.9$ & 27.5 \\
CRM142 & $\mathrm{Zn}$ & 4 & $92 \pm 3.0$ & 92.4 \\
IAEA436 & $\mathrm{Pb}$ & 2 & $0.14 \pm 0.01$ & 0.12 \\
IAEA436 & $\mathrm{Hg}$ & 2 & $4.36 \pm 0.05$ & 4.19 \\
IAEA436 & $\mathrm{Cd}$ & 2 & $0.053 \pm 0.02$ & 0.052 \\
IAEA433 & $\mathrm{As}$ & 2 & $17.2 \pm 0.02$ & 18.9 \\
CRM142 & $\mathrm{Mn}$ & 4 & $523 \pm 5.1$ & 569 \\
\hline
\end{tabular}

\section{RESULTS AND DISCUSSION}

Total metal ( $\mathrm{Pb}, \mathrm{Cd}, \mathrm{Hg}, \mathrm{Cu}, \mathrm{Zn}, \mathrm{Fe}$ and $\mathrm{Mn}$ ) concentrations in mussels (Mytilus galloprovincialis) and fishes (Merlangius merlangus euxinus) from the Southern Black Sea were investigated from 2005 to 2009 . Additionally, as contents were also measured in biota samples along the shelf. The concentrations of these elements are listed in Tables 3-6.

\section{Metals in mussels (Mytilus galloprovincialis)}

Lead concentrations varied between $4 \mu \mathrm{g} \mathrm{g}^{-1}$ and $25 \mu \mathrm{g}$ $\mathrm{g}^{-1}$ (dry wt.), $3 \mu \mathrm{g} \mathrm{g}^{-1}$ and $10.8 \mu \mathrm{g} \mathrm{g}^{-1}$ (dry wt.), $<0.01 \mu \mathrm{g} \mathrm{g}^{-1}$ and $1.1 \mu \mathrm{g} \mathrm{g}^{-1}$ (dry wt.) and $11.3 \mu \mathrm{g} \mathrm{g}^{-1}$ and $20.4 \mu \mathrm{g} \mathrm{g}^{-1}$ (dry wt.) in Mytilus galloprovincialis from 2005 to 2009, respectively (Tables 3a-6a). Lead levels in the Southern Black Sea shelf were found to be higher than the critical limits set by the both Turkish Ministry of Environment for Aquatic Products $\left(1 \mu \mathrm{g} \mathrm{g}^{-1}\right.$ wet wt.) and European countries $\left(2.0 \mu \mathrm{g} \mathrm{g}^{-1},{ }^{13}\right)$. The highest $\mathrm{Pb}$ levels were measured in 2009 , whilst the lowest values were measured in 2008.

Cadmium contents varied between $3.0 \mu \mathrm{g} \mathrm{g}^{-1}$ and $6.0 \mu \mathrm{g} \mathrm{g}{ }^{-1}$ (dry wt.), $<0.01 \mu \mathrm{g} \mathrm{g}^{-1}$ and $2.9 \mu \mathrm{g} \mathrm{g}^{-1}$ (dry wt.), $<0.01 \mu \mathrm{g} \mathrm{g}^{-1}$ and $0.58 \mu \mathrm{g} \mathrm{g}^{-1}$ (dry wt.) and $0.6 \mu \mathrm{g} \mathrm{g}^{-1}$ and $3.5 \mu \mathrm{g} \mathrm{g}^{-1}$ (dry wt.) in Mytilus galloprovincialis from 2005 to 2009, respectively (Tables 1a-4a). Cadmium levels in the Southern Black Sea shelf were found to be higher than the critical limits set by the Turkish Ministry of Environment for Aquatic Products ( $1 \mu \mathrm{g}$ $\mathrm{g}^{-1}$ wet $\mathrm{wt}$ ), similar to the previously mentioned $\mathrm{Pb}$ levels. While the highest Cd levels were measured in 2005, Cd levels were comparable from 2006 to 2009.

Mercury concentrations varied between $2 \mu \mathrm{g} \mathrm{g}^{-1}$ and 3.6 $\mu \mathrm{g} \mathrm{g}{ }^{-1}$ (dry wt.), $<0.01 \mu \mathrm{g} \mathrm{g}^{-1}$ and $0.24 \mu \mathrm{g} \mathrm{g}{ }^{-1}$ (dry wt.),$<0.01$ $\mu \mathrm{g} \mathrm{g} \mathrm{g}^{-1}$ and $0.02 \mu \mathrm{g} \mathrm{g}^{-1}$ (dry wt) and $0.04 \mu \mathrm{g} \mathrm{g}^{-1}$ and $0.13 \mu \mathrm{g} \mathrm{g}{ }^{-1}$ 
(dry wt.) in Mytilus galloprovincialis from 2005 to 2009 , respectively (Tables 3a-6a). Mercury levels in the Southern Black Sea shelf were found to be higher than the critical limits set by the Turkish Ministry of Environment for Aquatic Products $\left(0.5 \mu \mathrm{g} \mathrm{g}^{-1}\right.$ wet wt.) in 2005. On the other hand, the highest $\mathrm{Hg}$ contents were measured in 2005 , similar to the $\mathrm{Cd}$ findings.

\begin{tabular}{|c|c|c|c|c|c|c|c|}
\hline \multicolumn{8}{|c|}{$\begin{array}{c}\text { TABLE-3a } \\
\text { METAL CONTENTS OF MUSSELS (Mytilus galloprovincialis) } \\
\text { IN } 2005\left(\mu \mathrm{g} \mathrm{g}^{-1}\right)\end{array}$} \\
\hline 2005 & $\mathrm{Cu}$ & $\mathrm{Zn}$ & $\mathrm{Mn}$ & $\mathrm{Fe}$ & $\mathrm{Cd}$ & $\mathrm{Pb}$ & $\mathrm{Hg}$ \\
\hline Terkos & 60 & 208 & 73 & 1197 & 3 & 7 & 2 \\
\hline Zonguldak & 76 & 250 & 52 & 792 & 5 & 13 & 2.3 \\
\hline Bafra & 80 & 260 & 86 & 996 & 6 & 4 & 3.6 \\
\hline Ordu & 56 & 278 & 26 & 896 & 4 & 25 & 2.5 \\
\hline Aquatic product directory & 20 & $\mathbf{5 0}$ & - & - & 0.1 & 1.0 & 0.5 \\
\hline
\end{tabular}

\section{TABLE-3b}

METAL CONTENTS OF FISHES (Merlangius merlangus euxinus) IN $2005\left(\mu \mathrm{g} \mathrm{g}^{-1}\right)$

\begin{tabular}{lccccccc}
\hline 2005 & $\mathrm{Cu}$ & $\mathrm{Zn}$ & $\mathrm{Mn}$ & $\mathrm{Fe}$ & $\mathrm{Cd}$ & $\mathrm{Pb}$ & $\mathrm{Hg}$ \\
\hline Terkos & 11 & 48 & 19 & 609 & 1 & 3 & $<0.01$ \\
Zonguldak & 10 & 26 & 24 & 92 & $<0.01$ & $<0.01$ & $<0.01$ \\
Bafra & 11 & 22 & 20 & 19 & 3 & 2 & $<0.01$ \\
Ordu & 8 & 29 & 17 & 18 & $<0.01$ & $<0.01$ & $<0.01$ \\
Aquatic product Directory & $\mathbf{2 0}$ & $\mathbf{5 0}$ & - & - & $\mathbf{0 . 1}$ & $\mathbf{1 . 0}$ & $\mathbf{0 . 5}$ \\
\hline
\end{tabular}

\section{TABLE-4a}

METAL CONTENTS OF MUSSELS

(Mytilus galloprovincialis) IN $2006\left(\mu \mathrm{g} \mathrm{g}^{-1}\right)$

\begin{tabular}{lccccccc}
\hline 2006 & $\mathrm{~Pb}$ & $\mathrm{Cd}$ & $\mathrm{Zn}$ & $\mathrm{Mn}$ & $\mathrm{Fe}$ & $\mathrm{Cu}$ & $\mathrm{Hg}$ \\
\hline Ordu & 5.3 & 2.6 & 156 & 51 & 1317 & 62 & $<0.01$ \\
Rize & 10.8 & $<0.01$ & 63 & 56 & 1834 & 73 & 0.05 \\
Giresun & 3.8 & 1.5 & 79 & 28 & 924 & 8.0 & 0.02 \\
TRK13A & 1.7 & 0.2 & 118 & 23 & 930 & 12 & 0.08 \\
Sinop & 3.0 & 0.2 & 55 & 12 & 307 & 4.0 & 0.02 \\
Samsun & 3.4 & 1.3 & 122 & 12 & 521 & 26 & 0.17 \\
Trabzon & 7.1 & 2.9 & 31 & 63 & 2363 & 17 & 0.24 \\
TRK19A & 3.6 & 1.0 & 51 & 20 & 735 & 6.0 & 0.02 \\
Igne ada & 3.3 & 0.5 & 48 & 10 & 646 & 5.2 & 0.02 \\
Hopa & 7.5 & 1.0 & 232 & 17 & 430 & 29 & 0.02 \\
Aquatic product directory & $\mathbf{1 . 0}$ & $\mathbf{0 . 1}$ & $\mathbf{5 0}$ & - & - & $\mathbf{2 0}$ & $\mathbf{0 . 5}$ \\
\hline
\end{tabular}

\begin{tabular}{|c|c|c|c|c|c|c|c|}
\hline \multicolumn{8}{|c|}{$\begin{array}{c}\text { TABLE-4b } \\
\text { METAL CONTENTS OF FISHES (Merlangius } \\
\text { merlangus euxinus) IN } 2006\left(\mu \mathrm{g} \mathrm{g}^{-1}\right)\end{array}$} \\
\hline 2006 & $\mathrm{~Pb}$ & $\mathrm{Cd}$ & $\mathrm{Zn}$ & $\mathrm{Mn}$ & $\mathrm{Fe}$ & $\mathrm{Cu}$ & $\mathrm{Hg}$ \\
\hline Ordu & 18.0 & 0.5 & 85 & $<0.01$ & 91.2 & 0.5 & 0.02 \\
\hline Samsun & 9.3 & $<0.01$ & 21 & 7.4 & 216.4 & 1.0 & $<0.01$ \\
\hline Zonguldak & 8.9 & $<0.01$ & 38 & $<0.01$ & 87.7 & 0.8 & $<0.01$ \\
\hline Aquatic product directory & 1.0 & 0.1 & 50 & - & - & 20 & 0.5 \\
\hline
\end{tabular}

TABLE-5

METAL CONTENTS OF MUSSELS (Mytilus galloprovincialis) AND FISHES (Merlangius merlangus euxinus) IN $2008\left(\mu \mathrm{g} \mathrm{g}^{-1}\right)$

\begin{tabular}{lcccccc}
\hline 2008 & $\mathrm{Cd}$ & $\mathrm{Fe}$ & $\mathrm{Mn}$ & $\mathrm{Pb}$ & $\mathrm{Cu}$ & $\mathrm{Hg}$ \\
\hline Terkos & 0.13 & 394 & 1.8 & 1.1 & 1.7 & 0.41 \\
Zonguldak & 0.58 & 132 & 2.6 & $<0.01$ & 45 & 0.50 \\
Ordu & $<0.01$ & 21 & 1.1 & $<0.01$ & 0.8 & 0.14 \\
Aquatic Product Directory & $\mathbf{0 . 1}$ & - & - & $\mathbf{1 . 0}$ & $\mathbf{2 0}$ & $\mathbf{0 . 5}$ \\
\hline
\end{tabular}

Copper contents varied between $56 \mu \mathrm{g} \mathrm{g}^{-1}$ and $80 \mu \mathrm{g} \mathrm{g}^{-1}$ (dry wt.), $4.0 \mu \mathrm{g} \mathrm{g}^{-1}$ and $73 \mu \mathrm{g} \mathrm{g}^{-1}$ (dry wt.), $0.8 \mu \mathrm{g} \mathrm{g}^{-1}$ and $45 \mu \mathrm{g}$ $\mathrm{g}^{-1}$ (dry wt.) and $3.4 \mu \mathrm{g} \mathrm{g}^{-1}$ and $10.5 \mu \mathrm{g} \mathrm{g}^{-1}$ (dry wt.) in Mytilus galloprovincialis from 2005 to 2009, respectively (Tables 3a6a). Copper levels in the Southern Black Sea shelf were found to be higher than the critical limits set by the Turkish Ministry of Environment for Aquatic Products (20 $\mathrm{g} \mathrm{g} \mathrm{g}^{-1}$ wet wt.) in 2005, similar to the $\mathrm{Hg}$ findings. While the highest $\mathrm{Cu}$ levels were observed in 2005, the lowest $\mathrm{Cu}$ levels were found in 2009.

\begin{tabular}{|c|c|c|c|c|c|c|c|}
\hline \multicolumn{8}{|c|}{$\begin{array}{c}\text { TABLE-6a } \\
\text { METAL CONTENTS OF MUSSELS (Mytilus } \\
\text { galloprovincialis) IN } 2009\left(\mu \mathrm{g} \mathrm{g}^{-1}\right)\end{array}$} \\
\hline 2009 & $\mathrm{Cu}$ & $\mathrm{Cd}$ & $\mathrm{Pb}$ & $\mathrm{Fe}$ & $\mathrm{Zn}$ & As & $\mathrm{Hg}$ \\
\hline Terkos & 7.7 & 3.5 & 12 & 109 & 450 & 1.23 & 0.04 \\
\hline Sakarya & 5.2 & 1.3 & 17 & 576 & 425 & 0.86 & 0.07 \\
\hline Zonguldak & 7.7 & 0.6 & 13 & 122 & 108 & 0.41 & 0.09 \\
\hline Samsun & 3.4 & 0.9 & 11 & 24 & 43 & 4.85 & 0.13 \\
\hline Bafra & 4.3 & 1.4 & 20 & 83 & 146 & 0.53 & 0.12 \\
\hline Ordu & 6.0 & 3.0 & 15 & 45 & 801 & 3.22 & 0.13 \\
\hline Rize & 10.5 & 2.4 & 18 & 132 & 13 & 0.19 & 0.07 \\
\hline Aquatic product directory & 20 & 0.1 & 1.0 & - & 50 & 1 & 0.5 \\
\hline
\end{tabular}

\begin{tabular}{lcccccccc}
\multicolumn{8}{c}{ TABLE-6b } \\
\multicolumn{7}{c}{$\begin{array}{c}\text { METAL CONTENTS OF AND FISHES (Merlangius } \\
\text { merlangus e exinus })\end{array}$} \\
& $\mathrm{Cu}$ & $\mathrm{Cd}$ & $\mathrm{Pb}$ & $\mathrm{Fe}$ & $\mathrm{Zn}$ & $\mathrm{As}$ & $\mathrm{Hg}$ \\
\hline 2009 & 2.7 & 0.35 & 15 & 26 & 12 & 0.09 & 0.07 \\
\hline Terkos & 2.1 & 0.24 & 12 & 30 & 22 & 0.06 & $<0.01$ \\
Sakarya & 2.9 & 0.07 & 15 & 29 & 23 & 0.10 & 0.09 \\
Bafra & 3.4 & 0.22 & 13 & 106 & 41 & 0.03 & 0.5 \\
Ordu & $\mathbf{2 0}$ & $\mathbf{0 . 1}$ & $\mathbf{1 . 0}$ & & $\mathbf{5 0}$ & $\mathbf{1}$ & $\mathbf{0 . 5}$ \\
\hline Aquatic product directory & $\mathbf{2 0}$ &
\end{tabular}

Zinc concentrations varied between $208 \mu \mathrm{g} \mathrm{g}^{-1}$ and 278 $\mu \mathrm{g} \mathrm{g}{ }^{-1}$ (dry wt.), $31 \mu \mathrm{g} \mathrm{g}^{-1}$ and $232 \mu \mathrm{g} \mathrm{g}^{-1}$ (dry wt.) and $13 \mu \mathrm{g} \mathrm{g}^{-1}$ and $801 \mu \mathrm{g} \mathrm{g}^{-1}$ (dry wt.) in Mytilus galloprovincialis from 2005 to 2009, respectively (Tables 3a-6a). Zinc contents in the Southern Black Sea shelf were observed to be higher than the critical limits set by the Turkish Ministry of Environment for Aquatic Products (20 $\mu_{\mathrm{g} \mathrm{g}}{ }^{-1}$ wet wt.) from 2005 to 2009. The highest $\mathrm{Zn}$ levels were found in all sampling periods at the eastern of the shelf.

Iron contents varied between $792 \mu \mathrm{g} \mathrm{g}^{-1}$ and $1197 \mu \mathrm{g} \mathrm{g}^{-1}$ (dry wt.), $307 \mu \mathrm{g} \mathrm{g}^{-1}$ and $1834 \mu \mathrm{g} \mathrm{g}^{-1}$ (dry wt.), $21 \mu \mathrm{g} \mathrm{g} \mathrm{g}^{-1}$ and $394 \mu \mathrm{g} \mathrm{g}^{-1}$ (dry wt.) and $24 \mu \mathrm{g} \mathrm{g}^{-1}$ and $576 \mu \mathrm{g} \mathrm{g}^{-1}$ (dry wt.) in Mytilus galloprovincialis from 2005 to 2009, respectively (Tables 3a-6a). The highest Fe levels were found in 2005 and 2006, whilst the lowest Fe levels were measured in 2008 and 2009 along the shelf.

Manganese concentrations varied between $26 \mu \mathrm{g} \mathrm{g}^{-1}$ and $86 \mu \mathrm{g} \mathrm{g}^{-1}$ (dry wt.), $10 \mu \mathrm{g} \mathrm{g}^{-1}$ and $63 \mu \mathrm{g} \mathrm{g}^{-1}$ (dry wt.) and $1.1 \mu \mathrm{g}$ $\mathrm{g}^{-1}$ and $2.6 \mu \mathrm{g} \mathrm{g}^{-1}$ (dry wt.) in Mytilus galloprovincialis from 2005 to 2008, respectively (Tables 3a-5). The highest Mn levels were found in 2005 and 2006. On the other hand, the lowest Mn values were measured in 2008 along the Southern Black Sea shelf. The highest Mn levels were found in 2005 and 2006 whilst the lowest Mn values were measured in 2008.

Arsenic concentrations ranged from $0.19 \mu \mathrm{g} \mathrm{g}^{-1}$ and 4.85 $\mu g \mathrm{~g}^{-1}$ (dry wt.) in Mytilus galloprovincialis in 2009 (Table-6a). Contents were observed to be higher than the critical limits set by the Turkish Ministry of Environment for Aquatic Products (1.0 $\mu \mathrm{g} \mathrm{g}^{-1}$ wet wt.) at stations in Terkos, Samsun and Ordu. The lowest value was measured as $0.19 \mu \mathrm{g} \mathrm{g}^{-1}$ (dry wt.) at Rize station. 
Metals in fishes (Merlangius merlangus euxinus): Lead concentrations varied between $<0.01 \mu \mathrm{g} \mathrm{g}^{-1}$ and $3 \mu \mathrm{g} \mathrm{g}^{-1}$ (dry wt.), $9 \mu \mathrm{g} \mathrm{g}^{-1}$ and $18 \mu \mathrm{g} \mathrm{g}^{-1}$ (dry wt.), $<0.01 \mu \mathrm{g} \mathrm{g}^{-1}$ and $1.1 \mu \mathrm{g}$ $\mathrm{g}^{-1}$ (dry wt.) and $11.5 \mu \mathrm{g} \mathrm{g}^{-1}$ and $14.9 \mu \mathrm{g} \mathrm{g} \mathrm{g}^{-1}$ (dry wt.) in fishes (Merlangius merlangus euxinus) from 2005 to 2009, respectively (Tables 3b-6b). Lead levels in the Southern Black Sea shelf were found to be higher than the critical limits set by the both the Turkish Ministry of Environment for Aquatic Products $\left(1 \mu \mathrm{g} \mathrm{g}^{-1}\right.$ wet wt.) and European countries $\left(2.0 \mu \mathrm{g} \mathrm{g}^{-1},{ }^{13}\right)$. The highest $\mathrm{Pb}$ values were measured in 2006 and 2009, whilst the lowest values were measured in 2005 and 2008.

Cadmium contents varied between $<0.01 \mu \mathrm{g} \mathrm{g}^{-1}$ and $3 \mu \mathrm{g} \mathrm{g}^{-1}$ (dry wt.), $<0.01 \mu \mathrm{g} \mathrm{g}^{-1}$ and $0.5 \mu \mathrm{g} \mathrm{g}^{-1}$ (dry wt.), $<0.01 \mu \mathrm{g} \mathrm{g}^{-1}$ and $0.58 \mu \mathrm{g} \mathrm{g}^{-1}$ (dry wt.) and $0.07 \mu \mathrm{g} \mathrm{g}^{-1}$ and $0.35 \mu \mathrm{g} \mathrm{g}^{-1}$ (dry wt.) in fishes (Merlangius merlangus euxinus) from 2005 to 2009, respectively (Tables 3b-6b). Cadmium levels in the Southern Black Sea shelf were found to be higher than the critical limits set by the Turkish Ministry of Environment for Aquatic Products ( $1 \mu \mathrm{g} \mathrm{g}{ }^{-1}$ wet wt), similar to $\mathrm{Pb}$ findings. The variation in Cd levels was found to be similar during the 20052009 period.

While mercury concentrations were measured at the limit of the method $\left(<0.01 \mu \mathrm{g} \mathrm{g}^{-1}\right.$ dry wet $)$ in 2005 , they varied between $<0.01 \mu \mathrm{g} \mathrm{g}^{-1}$ and $0.02 \mu \mathrm{g} \mathrm{g}^{-1}$ (dry wt.), $0.14 \mu \mathrm{g} \mathrm{g}^{-1}$ and $0.50 \mu \mathrm{g} \mathrm{g}^{-1}$ (dry wt.) and $<0.01 \mu \mathrm{g} \mathrm{g}^{-1}$ and $0.09 \mu \mathrm{g} \mathrm{g}^{-1}$ (dry wt.) in fishes (Merlangius merlangus euxinus) from 2006 to 2009, respectively (Tables 3b-6b). Mercury contents were measured at their the highest values in 2008 along the shelf and they were found to be lower than the critical limits set by the Turkish Ministry of Environment for Aquatic Products $\left(0.5 \mu \mathrm{g} \mathrm{g}^{-1}\right.$ wet wt.) at all sampling periods. However, mercury levels in fish from the Southern Black Sea shelf were observed to have higher mercury levels those from the Marmara Sea ${ }^{14}$.

Copper contents varied between $8.0 \mu \mathrm{g} \mathrm{g}^{-1}$ and $11 \mu \mathrm{g} \mathrm{g}^{-1}$ (dry wt.), $0.5 \mu \mathrm{g} \mathrm{g}^{-1}$ and $1.0 \mu \mathrm{g} \mathrm{g}^{-1}$ (dry wt.), $0.8 \mu \mathrm{g} \mathrm{g}^{-1}$ and 45 $\mu \mathrm{g} \mathrm{g}^{-1}$ (dry wt.) and $2.1 \mu \mathrm{g} \mathrm{g}^{-1}$ and $3.4 \mu \mathrm{g} \mathrm{g}^{-1}$ (dry wt.) in fishes (Merlangius merlangus euxinus) from 2005 to 2009, respectively (Tables 3b-4b). Copper levels in the Southern Black Sea shelf were determined to be lower than the critical limits set by the Turkish Ministry of Environment for Aquatic Products ( $20 \mu \mathrm{g} \mathrm{g}^{-1}$ wet wt.) in all the sampling periods, similar to the $\mathrm{Hg}$ findings. The highest $\mathrm{Cu}$ level found, which was higher than the critical limit, was measured at Zonguldak station in 2008.

Zinc concentrations varied between $22 \mu \mathrm{g} \mathrm{g}^{-1}$ and $48 \mu \mathrm{g} \mathrm{g}^{-1}$ (dry wt.), $21 \mu \mathrm{g} \mathrm{g}^{-1}$ and $85 \mu \mathrm{g} \mathrm{g}^{-1}$ (dry wt.) and $12 \mu \mathrm{g} \mathrm{g}^{-1}$ and 41 $\mu \mathrm{g} \mathrm{g}^{-1}$ (dry wt.) in fishes (Merlangius merlangus euxinus) from 2005 to 2009, respectively (Tables 3b-6b). Zinc contents in the Southern Black Sea shelf were found to be lower than the critical limits set by the Turkish Ministry of Environment for Aquatic Products (20 $\mu \mathrm{g} \mathrm{g}^{-1}$ wet wt.) during 2005-2009 period. The highest $\mathrm{Zn}$ level, which was higher than the critical limit, was measured at Ordu station in 2006.

Iron contents varied between $18 \mu \mathrm{g} \mathrm{g}^{-1}$ and $609 \mu \mathrm{g} \mathrm{g} \mathrm{g}^{-1}$ (dry wt), $88 \mu \mathrm{g} \mathrm{g}^{-1}$ and $216 \mu \mathrm{g} \mathrm{g}^{-1}$ (dry wt.), $21 \mu \mathrm{g} \mathrm{g}^{-1}$ and $394 \mu \mathrm{g} \mathrm{g}^{-1}$ (dry wt.) and $26 \mu \mathrm{g} \mathrm{g}^{-1}$ and $106 \mu \mathrm{g} \mathrm{g}^{-1}$ (dry wt.) in fishes (Merlangius merlangus euxinus) from 2005 to 2009, respectively (Tables 3b-6b). The highest Fe values were measured at Terkos, Samsun and Ordu Stations along the shelf.
Manganese concentrations varied between $17 \mu \mathrm{g} \mathrm{g}^{-1}$ and $24 \mu \mathrm{g} \mathrm{g}^{-1}$ (dry wt.), $<0.01 \mu \mathrm{g} \mathrm{g}^{-1}$ and $7.4 \mu \mathrm{g} \mathrm{g}^{-1}$ (dry wt.) and $1.1 \mu \mathrm{g} \mathrm{g}^{-1}$ and $2.6 \mu \mathrm{g} \mathrm{g}^{-1}$ (dry wt.) in fishes (Merlangius merlangus euxinus) from 2005 to 2008, respectively (Tables 3b-5). The highest Mn levels were found in 2005 along the shelf. On the other hand, Mn values were lower than the detection limit of the method used $\left(<0.01 \mu \mathrm{g} \mathrm{g}^{-1}\right)$ in 2006 .

Arsenic concentrations ranged from $0.03 \mu \mathrm{g} \mathrm{g}^{-1}$ and 0.1 $\mu \mathrm{g} \mathrm{g}^{-1}$ (dry wt.) in fishes (Merlangius merlangus euxinus) from the Southern Black Sea shelf in 2009 (Table-6b). Levels were found to be much lower than the critical limits set by the Turkish Ministry of Environment for Aquatic Products (1.0 $\mu g \mathrm{~g}^{-1}$ wet wt.) along the shelf. Arsenic levels in fishes are comparable to or slightly higher than those found in the Marmara Sea ${ }^{14}$.

Total metal $(\mathrm{Cu}, \mathrm{Zn}, \mathrm{Cd}, \mathrm{Pb}$ and $\mathrm{Hg})$ contents of mussels (Mytilus galloprovincialis) were found to be much higher than the critical limits set by the Turkish Ministry of Environment for Aquatic Products along the Southern Black Sea shelf in 2005 (Table-3a). However, $\mathrm{Cu}, \mathrm{Zn} \mathrm{Fe}, \mathrm{Mn}$ and $\mathrm{Hg}$ contents of fishes (Merlangius merlangus euxinus) were low, contrary to the high $\mathrm{Pb}$ and $\mathrm{Cd}$ levels. While $\mathrm{Pb}, \mathrm{Cd}, \mathrm{Cu}$ and $\mathrm{Zn}$ contents were determined to be higher than the critical limits of Aquatic Product Directory along the shelf, $\mathrm{Hg}$ values were found to be lower (Table-2a) in 2006.

Cadmium and lead contents of fishes (Merlangius merlangus euxinus) were found at their highest values at Terkos and Bafra stations in 2005 (Table-3b). Copper, mercury and cadmium contents of fishes were measured at their lowest values, whereas $\mathrm{Pb}$ contents were higher than the critical limits of aquatic product directory in 2006 (Table-4b). In 2008, the highest $\mathrm{Cd}$ and $\mathrm{Cu}$ contents of mussels (Mytilus galloprovincialis) and fishes (Merlangius merlangus euxinus) were found at the Zonguldak station and the highest $\mathrm{Pb}$ values were measured at the Terkos station (Table-5). However, the Hg contents of all biota (Mytilus galloprovincialis and Merlangius merlangus euxinus) samples were lower than the limits of the aquatic product directory along the shelf. In addition, $\mathrm{Pb}$ contents were lower than the detection limit $(<0.01 \mu \mathrm{g} / \mathrm{L})$ of the method used at Zonguldak and Bafra stations. In 2009, Pb and Cd levels were found higher than the critical limits set by the Turkish Ministry of Environment for aquatic products $\left(1.0 \mu \mathrm{g} \mathrm{g}{ }^{-1}\right.$ and $0.1 \mu \mathrm{g} \mathrm{g}^{-1}$ dry wt, respectively) along the shelf. Iron contents were measured at their highest values at all stations, similar to the $\mathrm{Pb}$ and $\mathrm{Cd}$ levels encountered and zinc level in fishes (Merlangius merlangus euxinus) was measured as the highest value at station Ordu in 2006. In addition, the highest metal values, excluding mercury, were found in the eastern part of shelf.

Although $\mathrm{Fe}$ and $\mathrm{Mn}$ values had been set in the aquatic product directory, it was observed that these metal levels were quite high along the Southern Black Sea shelf during 20052009 period (Tables 3-6). It is known that $\mathrm{Mn}$ and Fe oxides and hydroxides coming to marine systems via rivers adsorb and co-precipitate dissolved metals and affects their enrichment ${ }^{15,16}$. In addition, the high Mn values in the western region can be correlated to inputs from the Binkiliç manganese mining zone $^{17}$.

In this monitoring programme (2005-2009), metal contents in mussels (Mytilus galloprovincialis) and fishes (Merlangius 
merlangus euxinus) ranked as follows: $\mathrm{Zn}>\mathrm{Fe}>\mathrm{Pb}>\mathrm{Cu}>$ $\mathrm{Cd}>\mathrm{As}>\mathrm{Hg}$ and $\mathrm{Fe}>\mathrm{Zn}>\mathrm{Pb}>\mathrm{Cu}>\mathrm{Cd}>\mathrm{As}>\mathrm{Hg}$, respectively. The highest values were generally found at harbours and river mouths. Several domestic discharge stations are exist at Zonguldak, Samsun, Ordu, Giresun, Trabzon and Rize. Besides, some industrial discharges stations such as iron and steel industry, thermal power plant, copper smelter and fertilizer plant are also exist at Eregli, Zonguldak and Samsun. For this reason, this study results are showed both the anthropogenic discharges (domestic + industrial) and terrestrial inputs from the mining zone in the rest of the shelf (Turkey mining Map, MTA; the scale of the map is 2,000,000) via rivers.

When our results were compared those of previous studies, it was clearly observed that $\mathrm{Cu}, \mathrm{Hg}$ and $\mathrm{Zn}$ contamination levels in fishes (Merlangius merlangus euxinus) from the Southern Black Sea shelf were higher than those of the Marmara sea, contrary to $\mathrm{Pb}$ levels encountered, which were much lower. Furthermore, $\mathrm{Cd}$ and As levels were comparable to or slightly higher than those from the Marmara Sea ${ }^{14,18,19}$ and Eastern Egean $\mathrm{Sea}^{20}$. Topçuoglu ${ }^{21}$ have also confirmed the heavy metal pollution in mytilus, fishes and surface sediments of the Middle and Eastern Black Sea shelf.

\section{Conclusion}

Lead, cadmium, mercury, zinc and arsenic levels of mussels (Mytilus galloprovincialis) and lead and cadmium contents of fishes (Merlangius merlangus euxinus) from the Southern Black Sea shelf are higher than the critical limits by the Turkish Ministry of Environment for Aquatic Products. On the other hand, the highest metal values are generally found at Harbours Eregli, Zonguldak, Samsun, Trabzon, Giresun, Ordu and Hopa and River mouths Sakarya, Yenice, Kozlu, Filyos, Kizilirmak and Yesilirmak and they show an increase towards the eastern end of the shelf. The effects of the Danube river can be observed in metal distributions, especially in the $\mathrm{Hg}$ levels of the west and middle of the Southern Black Sea shelf. The effect of deep discharges is seen at hot points Zonguldak, Samsun, Ordu, Giresun, Trabzon and Rize. Additionally, the anticyclone cycles significantly affect the vertical variations throughout the shelf. In this study, the results indicate the implications of the inputs from the mining zone on the rest of the shelf (Turkey mining Map, MTA; as the scale of the map 2.000.000) and the terrestrial anthropogenic (domestic + industrial) inputs via rivers. In conclusion, consumption of the both mussels (Mytilus galloprovincialis) and fishes (Merlangius merlangus euxinus) along the Southern Black Sea shelf is rising rapidly and the toxic effects, particularly of $\mathrm{Pb}$, $\mathrm{Cd}$, As and $\mathrm{Zn}$, will pose serious threats for human health.

\section{ACKNOWLEDGEMENTS}

The authors thank the captain, crew, scientists and technicians on board the RV Arar, Institute of Marine Sciences and the Management of Istanbul University for their help during the collection of Mytilus galloprovincialis and fish samples. This work was supported by the Turkish Ministry of Environment.

\section{REFERENCES}

1. T. Oguz, S. Tugrul, A. Kideys, V. Ediger and N. Kubilay, Chapter 33. Physical and Biogeochemical Charestic of the Black Sea (28, S) (2004).

2. U. Unluata, T. Oguz, M.A. Latif and E. Ozsoy, in ed.: L.J. Pratt, On the Physical Oceanography of Turkish straits. The Physical Oceanography of Sea Straits, NATO ASI Series, Kluwer, The Netherlands (1989).

3. E. Ozsoy and U. Unluata, Earth Sci.Rev., 42, 231 (1997).

4. Ö. Bastürk, E. Yakushev, S. Tugrul and I. Salihoglu, in eds.: S. Besiktepe, Ü. Ünlüata and A.S. Bologa, Characteristic Chemical Features and Biogeochemical Cycles in the Black Sea in Environnmental Degradation of the Black Sea: Challanges and Remedies, NATO Science Series/ Second Environmental Security, Netherlands, Vol. 56, p. 43 (1999)

5. Z. Ayas and D. Kolankaya, Bull. Environ. Contaminat. Toxicol., 56, 65 (1996).

6. F. Özkutlu, M. Turan, K. Korkmaz and Y.M. Huang, Asian J. Chem., 21, 4371 (2009).

7. U. Förstner and G.T.W. Witmann, Metal Pollution in the Environment. Berlin Heidelberg New York: Springer, p. 486 (1981).

8. J. Pempcowiac, A. Sikora and E. Biernacka, Chemosphere, 39, 313 (1999).

9. H. Hu, Prim. Care, 27, 983 (2000).

10. UNEP, Sampling of Selected Marine Organisms and Sample Preparation for the Analysis of Chlorinated Hydrocarbons. Reference Methods for marine pollution studies No.12 Rev.2 (1991).

11. UNEP, Determination of Total $\mathrm{Cd}, \mathrm{Zn}, \mathrm{Pb}$ and $\mathrm{Cu}$ in Selected Marine Organisms by Flameless AAS. Reference Methods for Marine Pollution Studies, No:11, Rev.1 (1984).

12. UNEP, Reference Methods for Marine Pollution Studies, No:14 (1982).

13. UNEP, GESAMP: Cadmium, Lead and Tin the Marine Environment. UNEP Regional Seas Reports and Studies No. 56 (1985).

14. A. Aksu, N. Balkis, O.S. Taskin and M.S. Ersan, Environ. Monit. Assesm., 182, 509 (2011).

15. L. Balisterieri and J.W. Murray, Geochim. Cosmochim. Acta, 48, 921 (1986).

16. N. Belzile, R. De Vitre and A. Tessier, Limnol. Oceanogr., 36, 1480 (1991).

17. A.H. Gültekin, Gechemistry and Origin of the Oligocene Binkiliç Manganese Deposit; Trace Basin, Turkey Third of Earth Sciences, Vol. 7, p. 11 (1998)

18. F. Kayhan, N. Balkis and A. Aksu, Ekoloji, 15, 61 (2006).

19. F. Kayhan, N. Gülsoy, N. Balkis and R. Yüce, Pakistan J. Biol. Sci., 10, 915 (2007).

20. F. Küçüksezgin, O. Altay, E. Uluturhan and A. Kontas, Water Res., 35, 2327 (2001).

21. S. Topçuoglu, Ç. Kirbasoglu and N. Güngör, Environ. Int., 27, 521 (2002). 